類かの RAM にまとめるといったととをやればよい であるう.

最後にスペース・ステーションであるが，スタディ の初期にはサターンVで大きなステーションを打ち上 げ，それを中核として，そのまわりにシャトルで打ち 上げられたモジュールをドッキングにより追加して大 きなステーションをつくる考えで進んでいたが, 最近

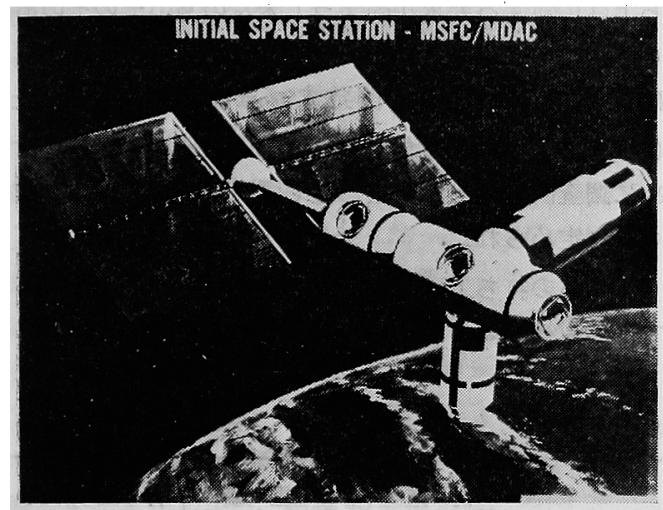

第18図初期のスペース・ステイション

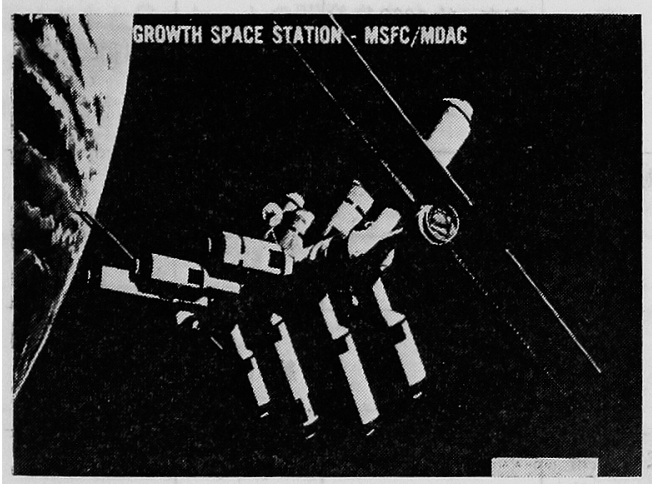

第19図大型スペース・スティション
にいたりすべてスペース・シャトルで運んで組み立て る力向に変わって来た.初めは第 18 図に示すような簡 単なもので, 6 名が居住可能であって電力は約 $15 \mathrm{~kW}$, 汎用実験室的なむのである。本格的なむのは第 19 図 のような形になるであろう. 各構成要素は将来とのよ うな姿になるととを想定して設計する必要がある.

\section{7. あとがき}

前述のような本年 1 月 5 日ニクンン大統領が，スペ ース・シャトルの本格的開発を承認した声名のなかで "continued pre-eminence of America and American industry がシャトルの一つの重要なぺイロードであ ろう”といっている点は興味樑い. この決定に伴って NASA は全面的にスペース・シャトルの開発へと動 き出したが，一方においてスペース・ステーションや スペース・タグは大幅に後退してしまった，特にタグ については当面国際協力として計画を進めないことと なたっので，欧州のスペース・タグは完全に宙に浮い た形になってしまった. さらにスペース・シャトルに 対する協力す会社を通じての下請的なすのしか考えら れなくなったもので欧州宇宙会議も，NASA の設け たポスト・アポロ計画への協为の期限 10 年末日を前に して未だに態度を決めかねているような状況にある。

日本は立ち後れていただけに害を受けることはは とんどなかったが，今後のポスト・アポロ計画の行方 には十分留意するとともに，長期間の方針について充 分検討する必要があろう。

\section{引用文献}

1) NASA: Post Apello Program Status Briefing for the European Space Conference, 1971.10.22.

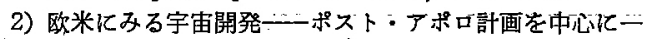
一経団連パンフレシト No.110 1971.11. p.9.

2) Aviation Week 1972.6.19. pp.36-37.

$\mathrm{N}$ 計画の現況と将来の展望*

\title{
Current Status and Future Prospect of the "N" Program
}

高田茂俊**
Shigetoshi TAKATA

1. まえがき

わが国の宇宙開発は，宇宙開発委員会において決定

* 昭和 48 年 3 月 15 日原稿受理.

** 宇宙開発事業団.

***. 宇宙開発事業団.

\author{
黒 田: 泰 弘***
Yasuhiro KURODA
}

される.“宇宙開発計画”.”.にとづき，科学研究の分野 においては東京大学が，実利用の分野においては宇宙 開発事業団が主体となって開発をすすめている.

現在の宇宙開発計画によれば，“実利用の分野におい ては，いわゆる “N計画”として，昭和 50 年から 52 年度本の間に，N口ケットを開発するとともに，技術 
試験衛星 I 型および II 型 (ETS-I，II), 電離層観測衛 星 (ISS), 実験用静止通信衛星 (ECS) の 4 種類の衛星 を開発して，種子島宇宙センターから打ち上げるとと が定められており，ての計画にしたがって，宇宙開発 事業団では，これらの人工衛星と打ち上げ用ロケット の開発のほか，種子島および筑波宇宙センターなどの 地上施設の開発整備ならびに打ち上げ，および追跡管 制業務等を推進している. $\mathrm{N}$ 計画は，昭和 45 年度の 決定以来, 逐次進展し, 現在, 衛星関係に扔いては初 期に打ち上げるもののプロトタイプ・モデルを製作中 であり，ロケット関係で浊実機の製作を開始してい る. また，各種の地上施設の開発整備も軌道にのり， いまや建設の最盛期に入ろうとしている。とのような 時機において，N計画の現状を報告し，さらに将来を 展望する機会を与えられたことを感謝したい。

\section{N計画の策定と将来の展望}

宇宙開発は, 研究と開発にあてられた最初の 10 年 を経て，世界は広籍な宇宙の利用時代を迎えつつあ り，いまや，宇宙空間の利用は国民生活の向上之産業 経済の発展に不可欠のもの之なって来た．わが国にお いて，関係の各方面加実用衛星の開発掞よびその打 ち上げに対する要求が高まって来たのも，そのそのあ らうれといえよう．昭和 45 年度決定の宇宙開発計画 においては，ただちに開発すぺき衛星として第 1 表 （その1）に示すすのが，また将来の要望に対好するた めに調查研究すべき衛星として同表（その2）に示す あのが定められた。

とれらの打ち上げ要求を充たすためのロケットとし ては，当初，QおよびNロケットが考えられていた。

第 1 表 実用衛星計画（その1）

\begin{tabular}{|c|c|c|c|c|}
\hline 街星名 項 目 & ミッション & 軌 道 & ，重 量 & 打ち上げ年度 \\
\hline $\begin{array}{l}\text { 技術試験衛星 I 型 } \\
(\text { ETS-I) }\end{array}$ & $\begin{array}{l}\text { ・ロケット打ち上げ技術の確認 } \\
\text { ・衛星追跡管制技術の畾得 } \\
\text { ・伸展アンテナの伸展実験 } \\
\text { ・衛星環境の測定 } \\
\text { ・衛星姿勢の測定 }\end{array}$ & $\begin{array}{l}\text { 高度：約 } 1000 \mathrm{~km} \\
\text { 円 軌 道 } \\
\text { 傾角 : } 47^{\circ}\end{array}$ & 約 $85 \mathrm{~kg}$ & 昭和50年度 \\
\hline $\begin{array}{c}\text { 電離層観測衛星 } \\
\text { (ISS) }\end{array}$ & 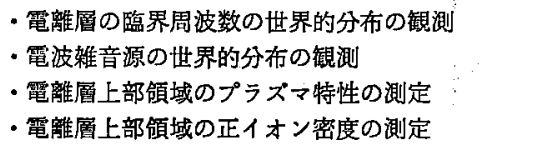 & $\begin{array}{l}\text { 高度 : 約 } 1000 \mathrm{~km} \\
\text { 円 軌 道 } \\
\text { 傾角 : 約 } 70^{\circ}\end{array}$ & 約 $120 \mathrm{~kg}$ & 昭和 50 年底， \\
\hline $\begin{array}{c}\text { 技術試験衛星 II 型 } \\
\text { (ETS-II) }\end{array}$ & 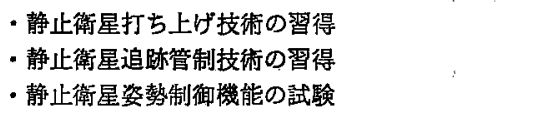 & $\begin{array}{l}\text { 同期軌道 } \\
\text { 傾角 : } 30^{\circ}\end{array}$ & 約 $130 \mathrm{~kg}$ & 昭和51年度 \\
\hline $\begin{array}{c}\text { 実験用静止通信䚘星 } \\
\text { (ECS) }\end{array}$ & 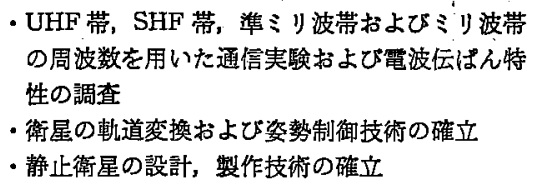 & 静止制道 & 約 $130 \mathrm{~kg}$ & 昭和 52 年度 \\
\hline
\end{tabular}

調查対象の実用街星（その2）

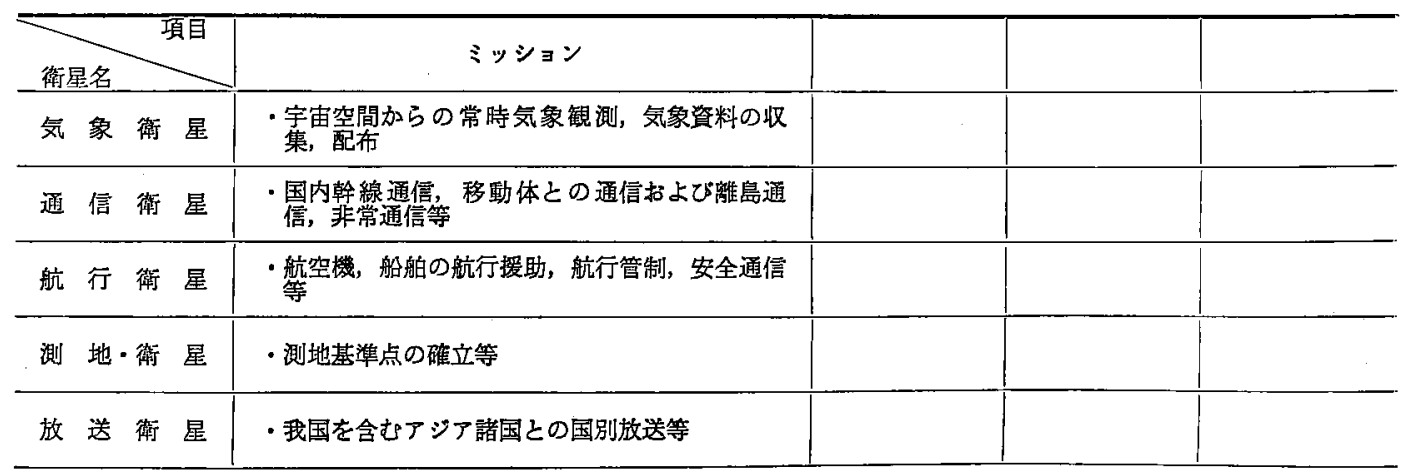


Qロケットは，それまで，日本において比較的開発経 験に富む固体口ケットを第 1 ，第 $2 ，$ 捛よび第 4 段に 使用し，高精度の誘導制御を行なうのに有利な液体口 ケットを第 3 段とする 4 段式ロケットであった．そし て，とのQを用いて電離層観測衛星などの中高度軌道 衛星を打ち上げ，次いで，その開発によって得られた 技術を基盤としてNロケットを開発し，実験用静止通 信衛星などの衛星を静止あるいは同期軌道に打ち上げ るとととしていた。

しかし，昭和 44 年 10 月，宇宙開発事業団が発足し て以来，乙の計画におりる開発の進捗状況などを詳細 飞検討した結果，今後解決すべき問題点が多く，打古 上げ時期の後れる公算が大きくなった，逆伅，衛星利 用者側婂あっては，もっと大型の衛星をできる限り早 い時期に打ち上げたいという要望が急速に高まり，ま た，その年 7 月に宇宙開発に対する日米政府間交換公 文が締結されて以来，米国より導入できる技術の笽围 などが，逐次明らかになって来た．てのような内外情 勢の変化にかんがみ，昭和 45 年度には，従来の宇宙 開発計画に対する見直しが行なわれ，結局，それまで 淮めて来たQロケットの開発を中止して，ソー・デル タの技術を大幅活用する新Nロケットの開発に直ち 飞着手し，塞用分野に批いて当面開発される衛星は，
すべてNロケットによって打ち上げられるてとが決定 された.

てれは，次第に大型化する衛星をできる限り早期に 打ち上げたいとの要望に岕ずるためには，性能向上の ための改良発展の可能性が比較的高い中型液体口ヶッ トの技術を，わが国として，一刻す早く確立する必要 があるとの判断に達したゆえであある.とうして新た 策定されたN計画には，宇宙開発の実用面において 立ち遅れたわが国が，出来る限り早く，確実に，経済 的に，口ケット之衛星を開発し，先進国の一員に仲間 入りするための実力を一日す早く婳養したいという願 望がてめられているといってよいであろう.

ところが，昭和 47 年度に入って，さらに重量250〜 $300 \mathrm{~kg}$ の静止気象衛星，実験用中容量通信衛星，中型 放送衛星などを，昭和 51 年度を目標に打ち上げたい というきわめて強い要望がなされて来た．これらの要 望は， ロケットの衛星打ち上げ能力の点からいって む, 開発スケジュールの点からいっても, 現行のN計 画の可能範囲をてえているので，要望に応ずるたるに は早急にNロケットの性能向上をはかる必要がある が，それ屯間に合わ婸合は，米国行打ち上げを依頼 することも考慮せねねばならぬほどきびしいものであっ た.

第 2 表 N口ケットの性能向上に対する技術的問題点

\begin{tabular}{|c|c|c|}
\hline & 項 目 & 技術点問題点 \\
\hline 1 段 & 体ロケットの่クラスター & 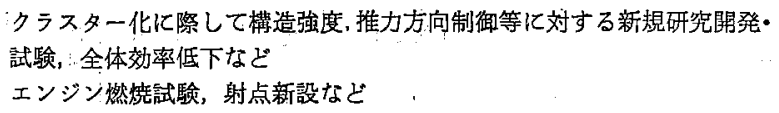 \\
\hline 1 段 & 体エンジンのクラスター & $\begin{array}{l}\text { 機体直径増大とエンジン取り付け部, 推力方向制御方式の変更等に対す } \\
\text { る新規研究開発・試験など } \\
\text { エンジン燃焼試験, 射点新設など }\end{array}$ \\
\hline 補增 & ブースタの個数增加 & 1 段機体のボート・テール改造など \\
\hline $\begin{array}{l}3 \\
1 \\
3\end{array}$ & ブースタの大型化 & $\begin{array}{l}\text { 大型ブースタの.開発と燃焼試験など } \\
\text { 機体側の構造強度に対する検討など }\end{array}$ \\
\hline$\stackrel{x}{\Phi}$ & ボート・テールの改造 & 上記に伴う改造と構造強度の㭘討など \\
\hline 1 段 & 维薬タンクの延長增量 & タンク材の新規加工技術など \\
\hline $2 の$ & アブレーション冷却式エンジン & 畺性 FRP の開発，エンシン燃焼試験など \\
\hline 登食 & 推進薬タンクの大型化 & 大型化に伴う貿作，試験など \\
\hline ト & 液体酸素/液体水素エンジン. & $\begin{array}{l}\text { 泎体水絜の製造, タービン・ポンプの開発, 燃焼試験, タンク模造, 断 } \\
\text { 蓺等長期の先行研究 }\end{array}$ \\
\hline 3 段 & ケット・モータの大型化 & モーターの大型化に伴なう開発・燃㸁試験など \\
\hline ノー & ・フェアリングの大型化 & 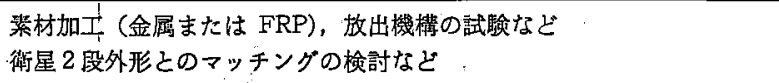 \\
\hline 誘方 & 電 波 誘 導 & 現行方式之原則的に同じ \\
\hline 導式 & 惯 性 誘 導 & 現行方式を全面変更するための長期の先行研究 \\
\hline
\end{tabular}




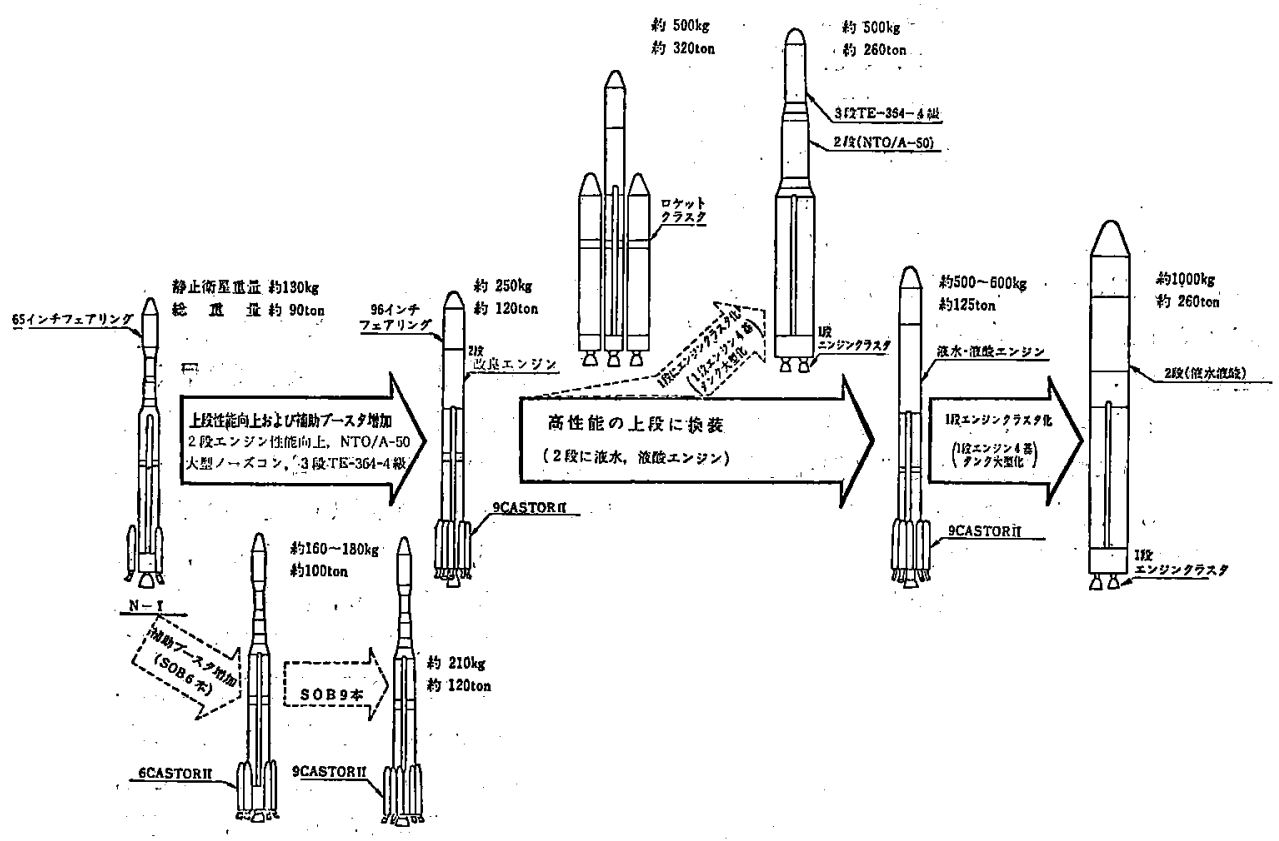

第 1 図 Nロケットの性能向上に対する構想。

第3表人工衛星の概要

\begin{tabular}{|c|c|c|c|c|c|}
\hline 人工衛星の種類 & ETS-I & ISS & ETS-II & ECS & 備 考 \\
\hline $\begin{array}{l}\text { 状 } \\
\text { 法 } \\
\text { 量 }\end{array}$ & $\begin{array}{l}\int_{\text {内直径 } 80 \mathrm{~cm} \text { の球に }}^{\text {接する26面体 }} \\
\text { 約 } 85 \mathrm{~kg}\end{array}$ & $\begin{array}{l}\text { 直径 } 94 \mathrm{~cm} \text {, 高さ } \\
82 \mathrm{~cm} \text { の円筒形 } \\
\text { 約 } 120 \mathrm{~kg}\end{array}$ & $\begin{array}{l}\text { 直径約 } 140 \mathrm{~cm} \text { ：高 } \\
\text { き約,90 cm の円筒形 } \\
\text { 約 } 130 \mathrm{~kg}\end{array}$ & $\begin{array}{l}\text { 直径約 } 140 \mathrm{~cm} \text {, 高 } \\
\text { さ約 } 90 \mathrm{~cm} \text { の円筒形 } \\
\text { 約 } 130 \mathrm{~kg}\end{array}$ & \\
\hline 道 & $\begin{array}{l}\text { 高度 約 } 1,000 \mathrm{~km} \\
\text { 軌道傾斜角 約 } 47 \text { 度 }\end{array}$ & $\begin{array}{l}\text { 高度 約 } 1,000 \mathrm{~km} \\
\text { 轨道傾斜角 約 } 70 \text { 度 }\end{array}$ & $\begin{array}{l}\text { 高度 約 } 36,000 \mathrm{~km} \\
\text { 東経 } 130^{\circ} \\
\text { 轨道 同期軌道 }\end{array}$ & $\begin{array}{l}\text { 高度 約 } 36,000 \mathrm{~km} \\
\text { 東経 } 140^{\circ} \\
\text { 轨道 静止軌道 }\end{array}$ & \\
\hline 命 & 約 3 力月 * $90 \%$ 以上 & 1.5 年 ${ }^{*} 70 \%$ 以上 & 約 6 力月 $* 80 \%$ 以上 & 約 1 年 ${ }^{*} 60 \%$ 以上 & *残存確率 \\
\hline ミッション & 第 1 表そのと同じ & & & & \\
\hline 能 & $\begin{array}{l}\text { ・打ち上げ時および } \\
\text { 軌道上の環境デー } \\
\text { タ取得 } \\
\text { - 姿勢データ取得 } \\
\text { • 追跡データ取得 } \\
\text { ・伸展アンテナ実験 }\end{array}$ & $\begin{array}{l}\text { ・電離層の世界分布 } \\
\text { の観測 } \\
\text { ・電波雑音の世界分 } \\
\text { 布の観測 } \\
\text { ・プラズマ測定 } \\
\text { ・正イオン密度測定 }\end{array}$ & 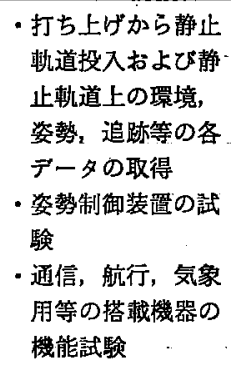 & 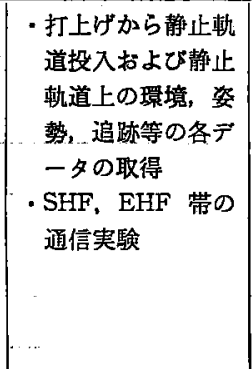 & \\
\hline 姿 勢 制 & $\begin{aligned} \text { ・ スピン安定 } \\
\text { 初期100rpm } \pm 10 \% \\
=\text { ニーテーショ } \\
\text { ン・ダンパー }\end{aligned}$ & $\begin{array}{l}\text { ・スピン安定 } \\
\text { 初期 } 130 \mathrm{rpm} \\
\text { 1.5年後-10\%以下 }\end{array}$ & $\begin{array}{l}\text { ・ スピン安定 } \\
100 \mathrm{rpm} \pm 10 \%\end{array}$ & $\begin{array}{l}\text { ・ スピン安定 } \\
100 \mathrm{rpm} \pm 10 \%\end{array}$ & \\
\hline 熱＼cjkstart制 & 受動 型 & 受動 型 & 受 動 型 & 受動 型 & \\
\hline
\end{tabular}


てれを受けた宇宙開発委員会におかれては，衛星側 における要望の必要性と緊急性, 打ち上げの可能性な どについて，慎重な検討を重ねた結果，静止気象衛星 につ়いては昭和 48 年度より開発に着手し, 通信衛星, 放送衛星については開発研究を進めるととを決定さ れた：また，Nロケットについては，その性能を向上 するための改良発展の方法および順序などについて討 議されたが，今後引き続いてさらに詳細な検討を重ね ることとされた。

Nロケットは，前述のように，もともと性能向上の ための改良発展の可能性が高いロケットとして選定さ れたものであって，禣助プースタの増強や，“上段部口 ケットの改良などによって，効率よく着実に，衛星打 ち上げ能力を増すことができる．とくに，2段目に液 体酸素・液体水素ロケット・エンジンを採用すること によって，飛躍的に性能を向上することができる．さ らに，第 1 段液体口ケット・エンジンを数個束るてク ラスタとしたり，あるいは，第1段ロケットそのあの をクラスタとすることによって，より大きな打ち上げ 能力をあたせるととも可能と考えられる. 第 2 表は, それらの各場合における技術的問題点を示したもので あり，第 1 図は，そのような問題点を考慮しなから， 逐次技術をつみ上げ，順を追って大型化をはかる開発 構想の一例を示したものである.これとあわせて，口 ケットの慣性誘導, 衛星の軸姿勢制御などの技術も, 将来のために開発を急ぐ必要があろう.

てのようなロケットの大型化や精度・性能の向上と 開発完成時期が, 衛星利用者側の要望に対応できるか どうか，るしそれが困蜼な場合にはどう対処すべきか など, 開発所要経費や開発完成時に予想される世界情
勢などああわ甘考虑して，今後の方針が検討されるこ ととなるであろう。

\section{3. $\mathrm{N}$ ロケットの開発}

現在のN口ケットの開発計画は，とくにその初期段 階において，米国よりの大幅な技術援助を受け入れな がら進めるとととしている，すなわち：わが国ではほ とんど経験のない分野であり，かつ開発には，最も多 額の費用ど長期の時間を要する第 1 段の液体ロケッ ト・エンジン (LOX/RJ-1) ならびに機体構造につい ては，ライセンス生産とし，從来，日本である程度開 発が進められており，比較的小型で，第 1 段に比べて それ程多大の費用と時間を要しない第 2 段の液体口ケ ット・エンジン (NTO/AJ-50), と機体構造に対して は米国の技術援助は受けるむのの，自主開発を基調上 して進めるとととしている.まだ，第 1 段の補助ブー スタや第 3 段の固体口ケットに対しては，当面は米国 のものを導入するが，将来は，てれまでわが国でつみ 上げられて来た固体ロケットの技術を活用することを 考えながら，それらの開発を進めることとしている. さらに，技術的に最す困難な誘導制御システムについ ては，当面は米国より信頼性の高い部品を購入する が,やがては，日本であシステム開発を進められる可 能性の高い方式を採用するとととしている.

以上で明らかなように，Nロケットにおける自主的 開発の努力の焦点は，第 2 段の液体ロケット・エンジ ンと誘導制御システムにあるが，乙れらに関する基礎 技術を開発するために，LSC, JCR などの小型ロケッ トの打ち上げ実験を行なっており．また，Nロケット の本番打ち上げの前段階として, 試験用ロケットMの

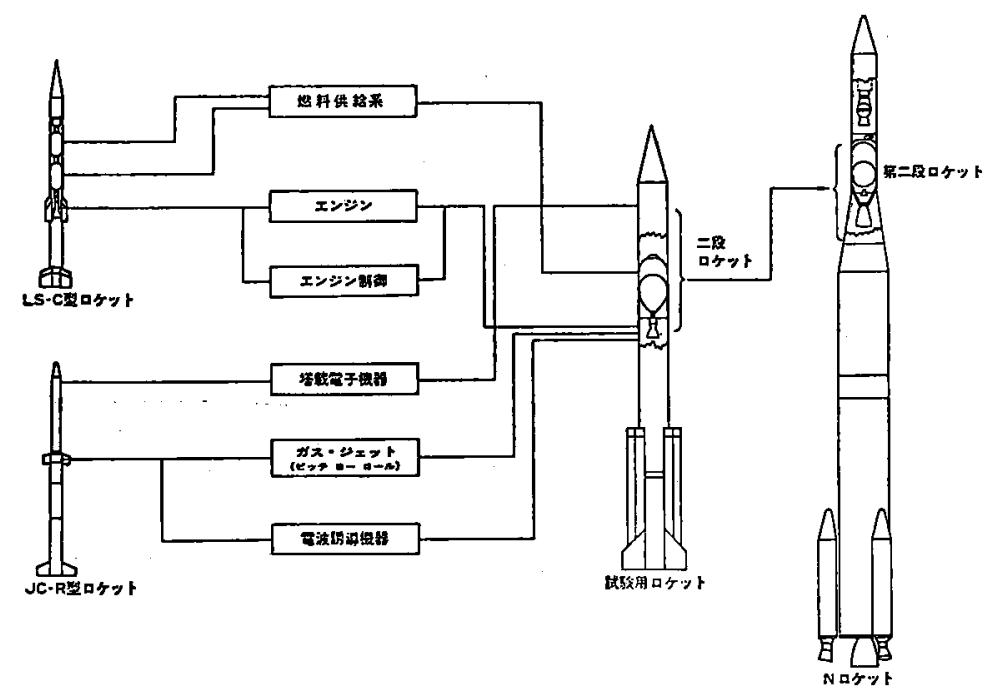

第 2 図 小型书よび試験用ロケットとNロケットとの関係 
打ち上げ実験を予定している，試験用ロケットは，そ の第 1 段に, 東京大学で開発された $\mathrm{M}$ ロケットの第 1

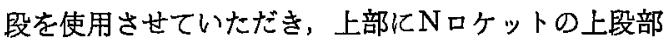
を組み合わせたものである，第 2 図は，N口ケットに 打ける技術要素が LSC, JCR から試験用ロケットを 経て，Nにつなげられる過程を示したあのである. ま た，N口ケット打ち上げに先立って，口ケットと地上 の施設設備之の整合性を総合的に試針し，打ち上げ管 制作業などの訓練などにあ資するため，GTV（地上 試験用ロケット）を製作するとととしている，GTV
による試験と訓練が終わった後に，N口ケットが発射 台上に運ばれることになる。

また，電離層観測衛星にさき立って，同じ高度の軌 道に技術試験衛星 I 型を打ち上げ，実験用静止通信衛 星にさき立って技術試験衛星 II 型を同期軌道に打ち 上げるとととし，Nロケットの能力を十分に確認する ようつとめている.

第 3 図はNロケットの全体形状第 4,5,6 図はそれぞ れ第 $1,2,3$ 段のエンジン，第 7 図は誘導装置のブロッ ク図を示すむのである.
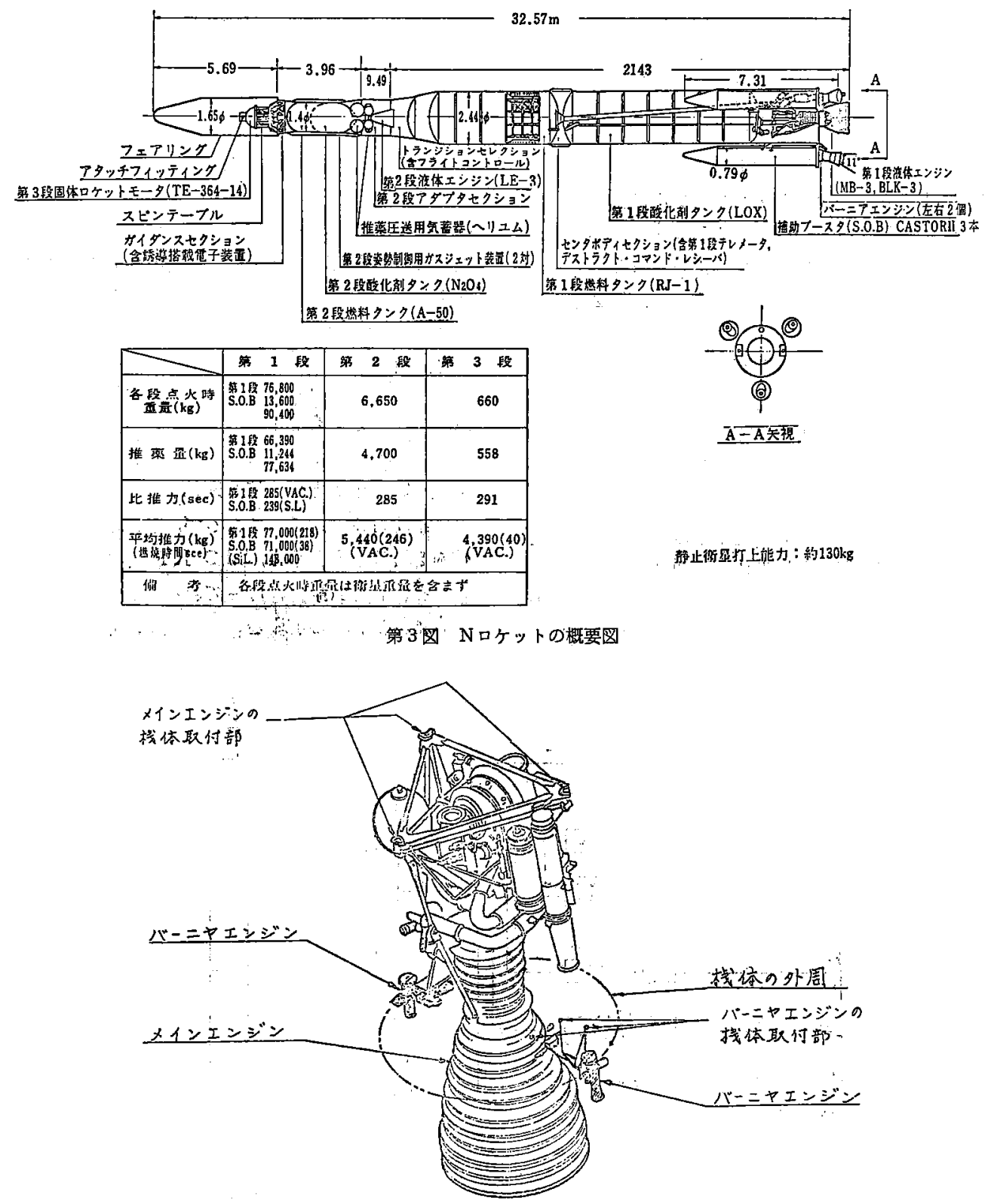

第 4 図 第 1 段のメイン・エンジンとパーニャエシジンの機体取付困 


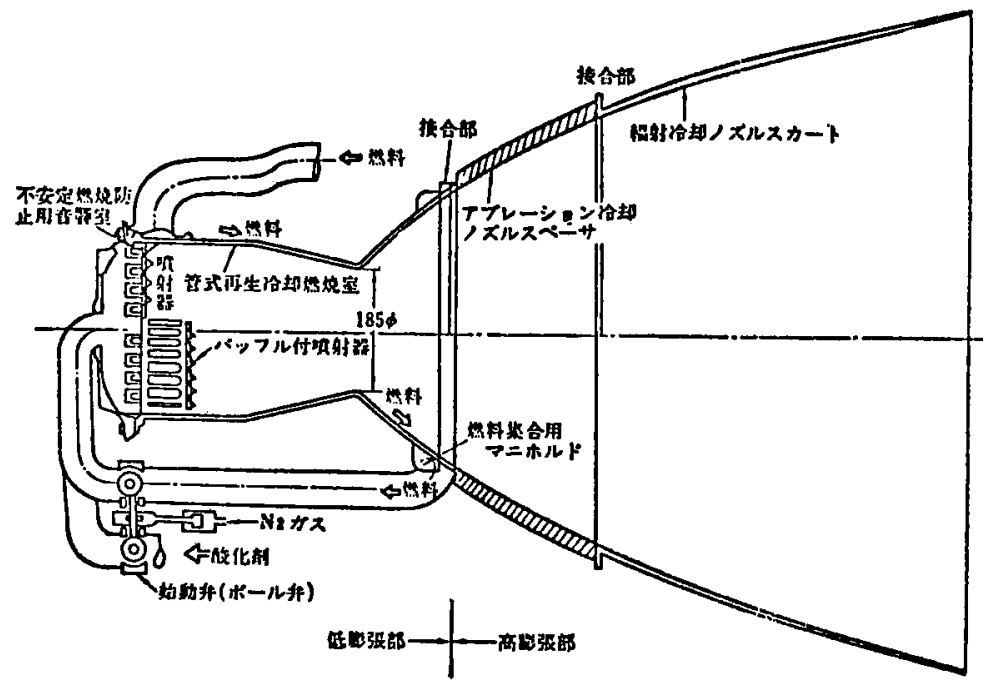

第 5 図 第 2 段エンジン

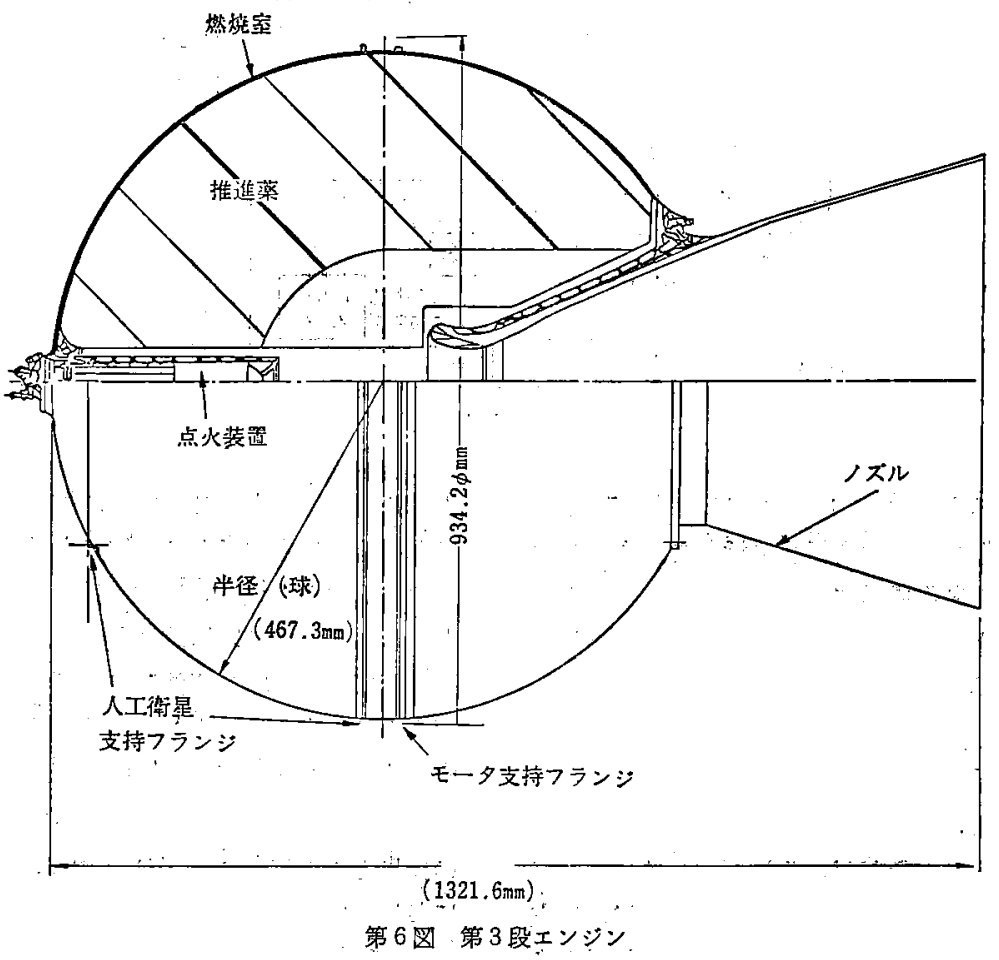




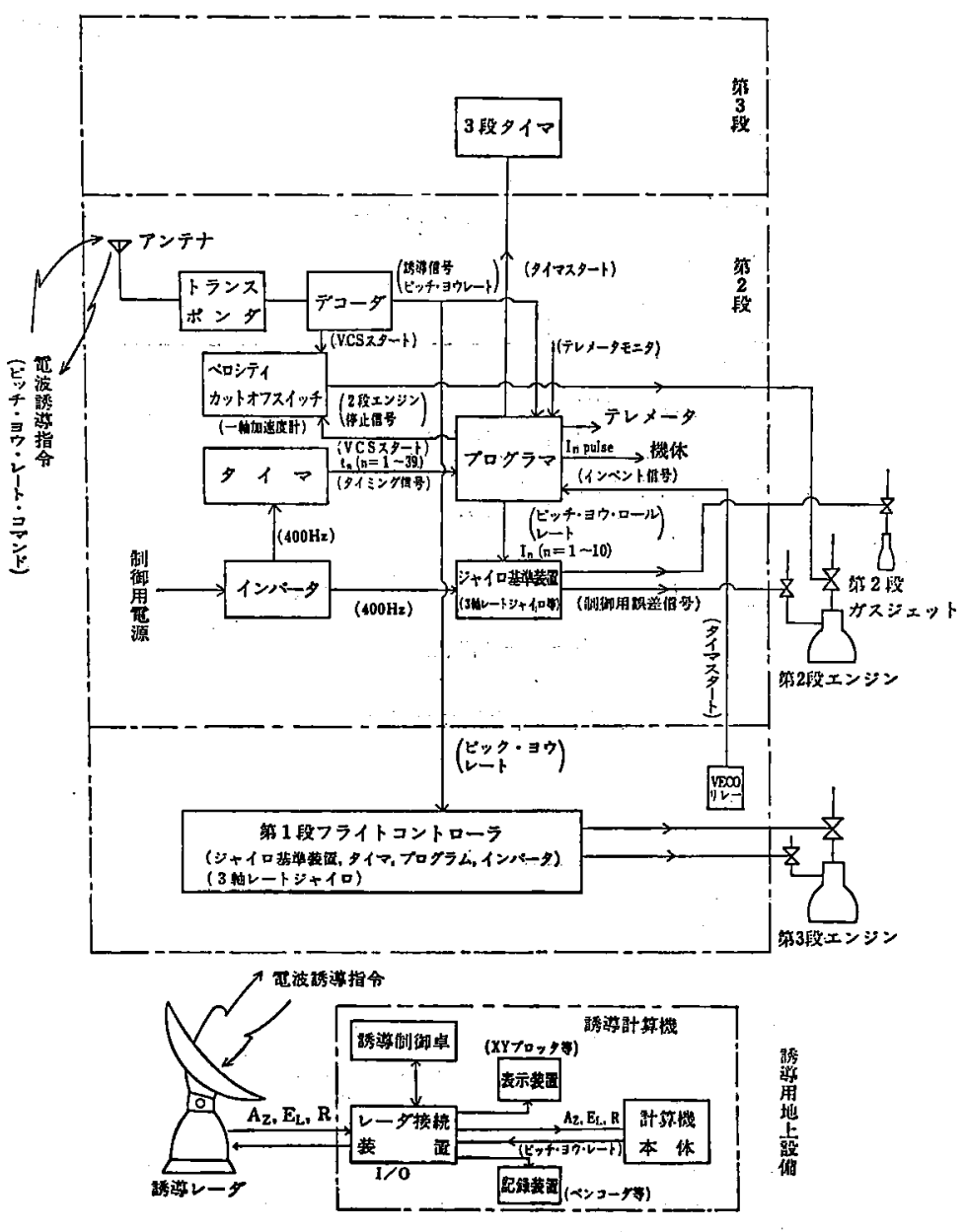

第7図 Nロケット誘導装圈ブロック図

現段階におけるNロケットの開発は，昭和 50 年中 期に予定の初号機打ち上げを目睷に控えて，全面的な ハード・ウェヤの製作段階に進むとともに，飛しよう 解析などのソフト・ウェヤ面においても詰めと整销を 急いでいるところである.

\section{4. 人工衛星の開発}

N計画において，当面，その開発と打ち上げが定め られている実用分野の衛星は，先に述へた 4 種類（第 3 表)であるか，開発をすすめるにあたっては，自主 開発を基調とし，必要に応じて米国よりの技術援助を 受け，また一部の信頼性部品を購入することとしてい る.

技術試験衛星 I 型 (ETS-I) はN ロケットによって 打ち上げられる最初の衛星で，中高度円轨道（1，000 $\mathrm{km}$ ）投入する人工衛星打ち上げ技術の習得を主目 的としている. との衛星の開発は昭和 45 年に始めら れたが，昭和 50 年夏期における打ち上げを目指して，
まず順調な進渉を見せている，第8困に ETS-I の外 観を第 9 良塔载機器の系統图を示す.

電離層観測衛星 (ISS) は ETS-I に引き続いて打ち 上げられる衛星で，短波通信の効率化をはかるため， 電離層に找りる臨界周波数の世界的分布を定常的に観 測することを主目的としている，乙の衛星の開発は， 昭和 42 年度加ら郵政省電波研究所の手によって開始 されたが，昭和 44 年 10 月になって，宇宙開発事業団 の発足とともに引き継がれ，現在，昭和 50 年度末期 における打占上げ（高度 $1,000 \mathrm{~km}$ 円軌道，傾斜角 $70^{\circ}$ ) を目指してハード・ウェヤの製作之試験が続けら れているととろである. 第 10 図に ISS の外観を, 第 11 因に搭载機器の系統図を示す.

技術試験衙星 II 型 (ETS-II) は, 静止衛星打ち上げ 技術の習得を主目的とする衛星で, 昭和 46 年度に高 々度衛星としてのシステム解析を開始し，51 年度に 打ち上げることを目標として開発を進めている.

実験用静止通信衛星 (ECS) は, 準ミリ波およびミ 
第 4 表，種子島宇宙センターの概要（主要機能，設備）

\begin{tabular}{|c|c|c|}
\hline 区 分 & 主 要 機 能 & 主要括設設備 \\
\hline 指 令 系 & $\begin{array}{l}\text { 発射整倩，発射の総合的管理など（レンジ・セーフ } \\
\text { ティを含む） }\end{array}$ & $\begin{array}{l}\text { レンジ・コントロール・センター } \\
\text { 発射管制設備, 時刻設備, 地上安全設備, 飛行安全 } \\
\text { 設備など }\end{array}$ \\
\hline 通 信 系 & 各系間のデータ伝送，音声伝送など： & $\begin{array}{l}\text { マイクロ波通信設備，搬送通信設備，電話設備，デ } \\
\text { ータ通信用端末設備など }\end{array}$ \\
\hline 射 点 采 & $\begin{array}{l}\text { ロケット, 人工街星の発射前組立, チェックアゥト, } \\
\text { カウント・ダウンなど }\end{array}$ & $\begin{array}{l}\text { ロンチ・デッキ, アンビリカル・マスト, 整備塔, } \\
\text { チェックアウト装置など }\end{array}$ \\
\hline 電 波 采 & $\begin{array}{l}\text { 人工衛星およびロケットの追尾; 電波指令誘道，テ } \\
\text { レメータ・データ取得，飛行中断など . . . . . . }\end{array}$ & $\begin{array}{l}\text { 中距離追尾レーダー,コリメーション設備, 誘導レ } \\
\text { ーダー設備, 衛星テレメータ・コマンド設備など }\end{array}$ \\
\hline 光 学 系 & 光学追尾 & シネセオドライト,レンジ・セーフティ光定設備など \\
\hline 気 象 系 & $\begin{array}{l}\text { 䅅子島宇宙センターの定常的気象観測および打ち上 } \\
\text { げのための気象予報, 風速等の気象観測など }\end{array}$ & 気象塔観測設供，地上気象観測設備など \\
\hline 試 験 系 & $\begin{array}{l}\text { ロケット，人工衛星について，射点亲に移行する前 } \\
\text { の発射整借 }\end{array}$ & $\begin{array}{l}\text { 組立試験設備, 第 } 3 \text { 段スピン試験装置衛星チェック } \\
\text { アウト装置など }\end{array}$ \\
\hline 燃燒武験系 & ロケット・モータ，ロケット・エンジンの燃焼試験 & $\begin{array}{l}\text { 液体ロケット燃焼試験設備, 固体ロケット燃焼試験 } \\
\text { 設備など }\end{array}$ \\
\hline 支 援 系 & 各系への給電, 給排水など & $\begin{array}{l}\text { 発送配電，給排水施設設備，燃料，酸化肪咛蔵庫な } \\
\text { ど }\end{array}$ \\
\hline 管 理 系 & 管理事務，宿舎など & 管理事務所, プレス・センター, 宿舎など \\
\hline 小型射場系 & 小型ロケット飛しょう試験 & \\
\hline
\end{tabular}

(注) 小型射場を除く各系には， $Q^{\prime}$ 用のあのと NLV-I/(ELS-I, ISS，ETS-II および ECS) 用のものが含まれる.

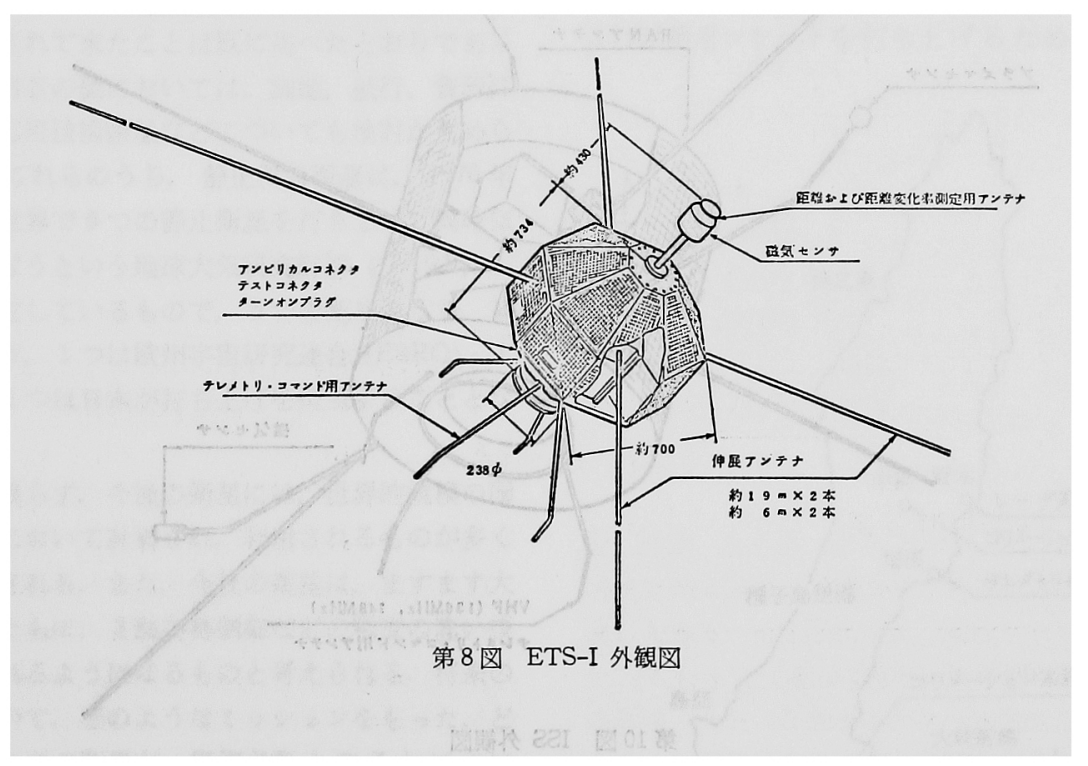




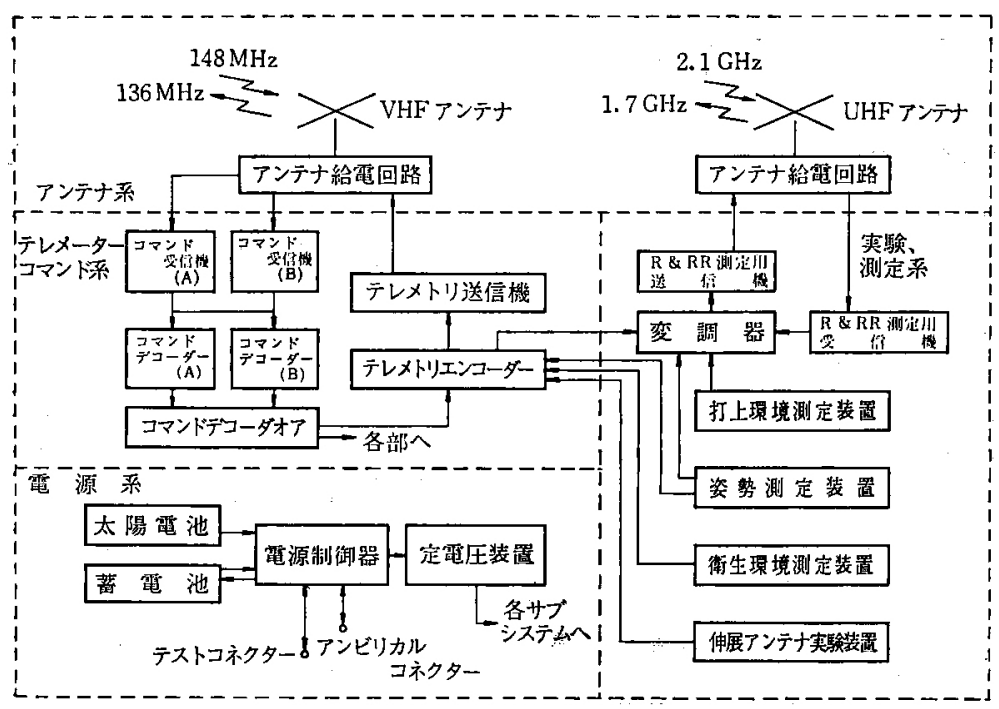

第 9 図 ETS-I 搭载機器系統図

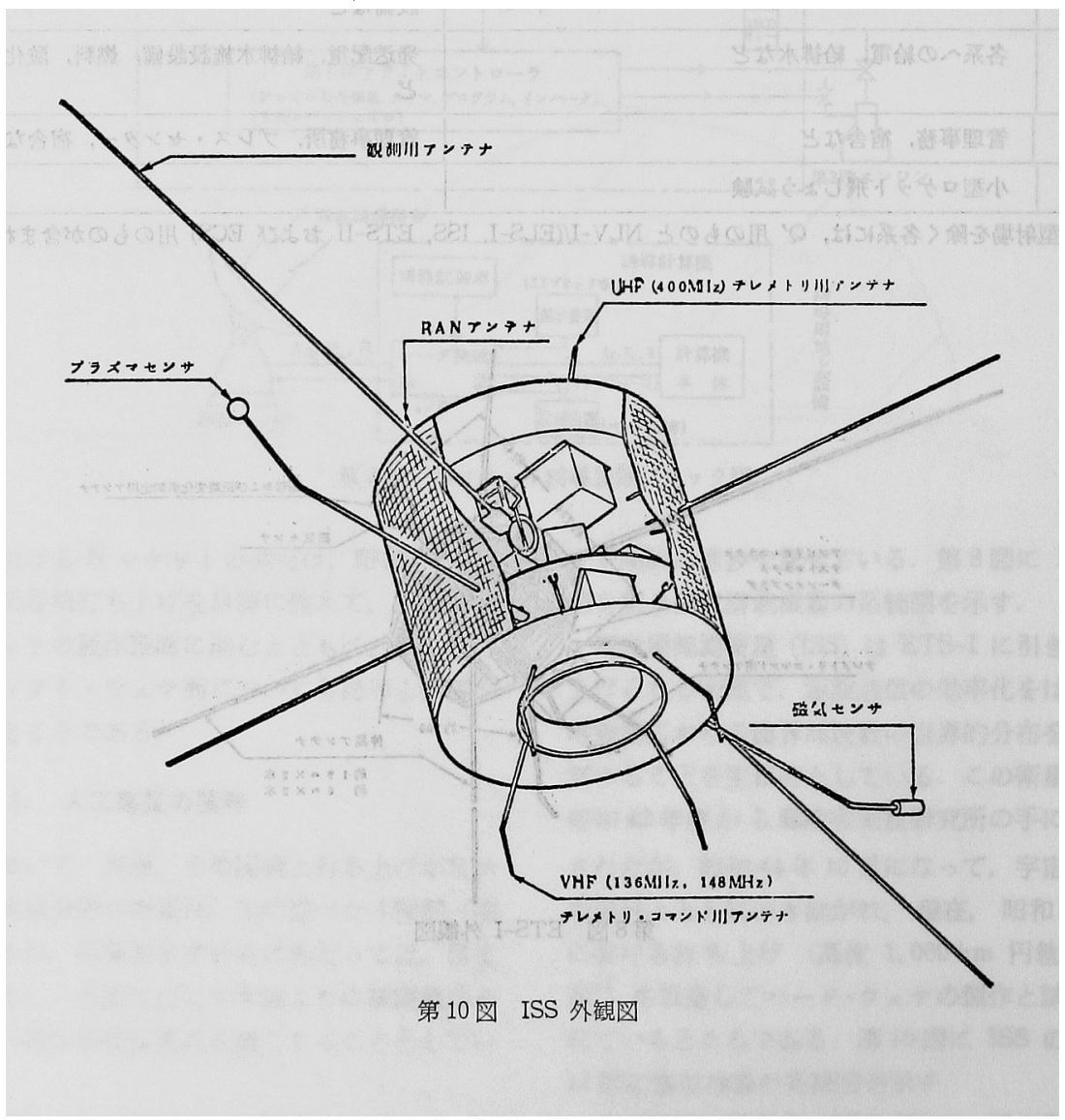




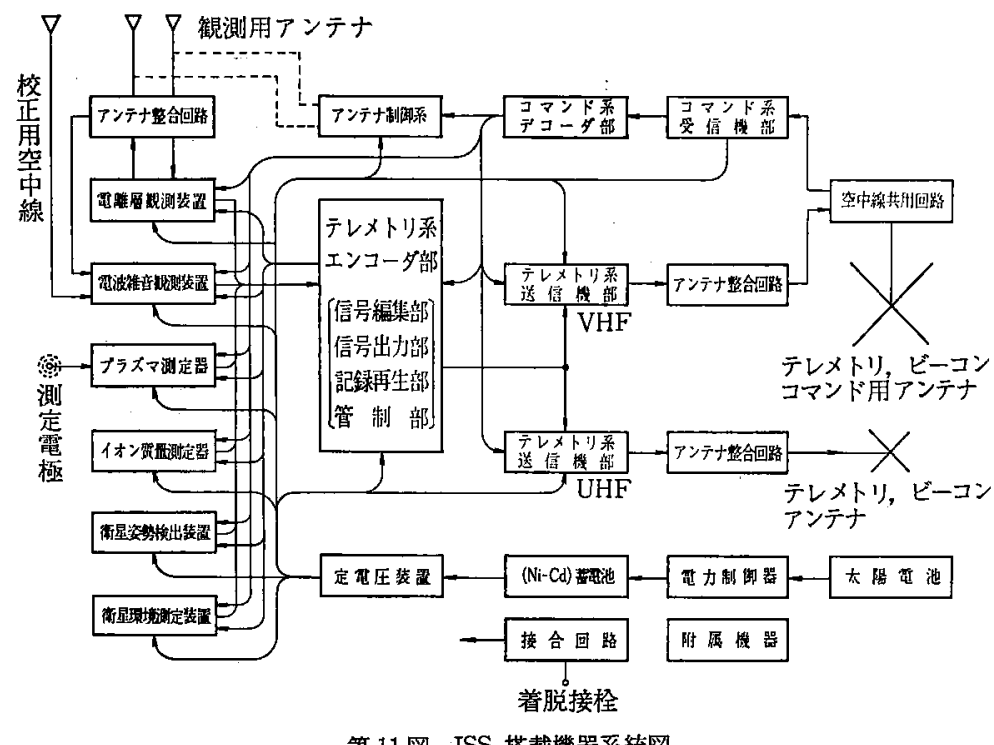

第 11 図 ISS 搭载機器系統図

リ波の通信実験などを行なうことを主目的とする衛星 で，昭和 46 年度に ETS-II とあわせて高々度衛星と してのシステム解析を開始し，52 年度に打ち上げる

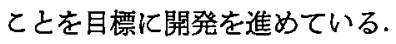

以上，4 種類の衛星のほか，最近になって，静止気 象衛星, 実験用中容量通信衛星, 中型放送衛星などの 要望が提起されて来たととは既に述べたとおりである が, 衛星利用者の側においては, 测地, 航行, 資源探 査, および応用技術衛星などについても検討が進めら れている．とれらのうち，静止気象衛星は，1976 年 を目標に，世界で $5 つ$ 静止衛星を打ち上げて同時気 象観測を行なうという地球大気研究計画 (GARP) 几 の参加を決定しているむので，5つの衛星のうち， 2 つはアメリカ, 1 つは欧州宇宙研究連合 (ESRO), 1 つはソ連，1つは日本が打ち上げを担当することとな っている.

乙の例に限らず，今後の衛星には，世界的規模の国 際協力の場汇扔いて計画され，利用されるすのが多く なると予想される．また，今後の衛星は，ますます大 型化するとともに，3軸姿勢制御などの精度の高い技 術が要望されるようになるすのと考えられる. 将来の わが国において，どのようなミッションをもった，と のような大きさの衛星が，幾個必要となるかについ て，十分の研究調査と検討がなされねばならないであ ろう.

\section{5. 地上施設の開発整備}

N計画の地上施設としては，種子島と筑波の両宇宙 センター, および勝浦, 沖縄の電波観湘所, ダウン．
レンジ局などの開発整備がある.

種子島宇宙センターは，昭和 41 年, 当時の宇宙開 発推進本部によって島の南端に近い竹崎地区に建設が 始められ，44年夏までには，LSC, JCR などの小型口 ケットを打ち上げる射場施設の建設を一応完成した. 竹崎射場の北方に位置する大崎射場は，Nロケットお よび試験用ロケットを打ち上げるためのむので, 現

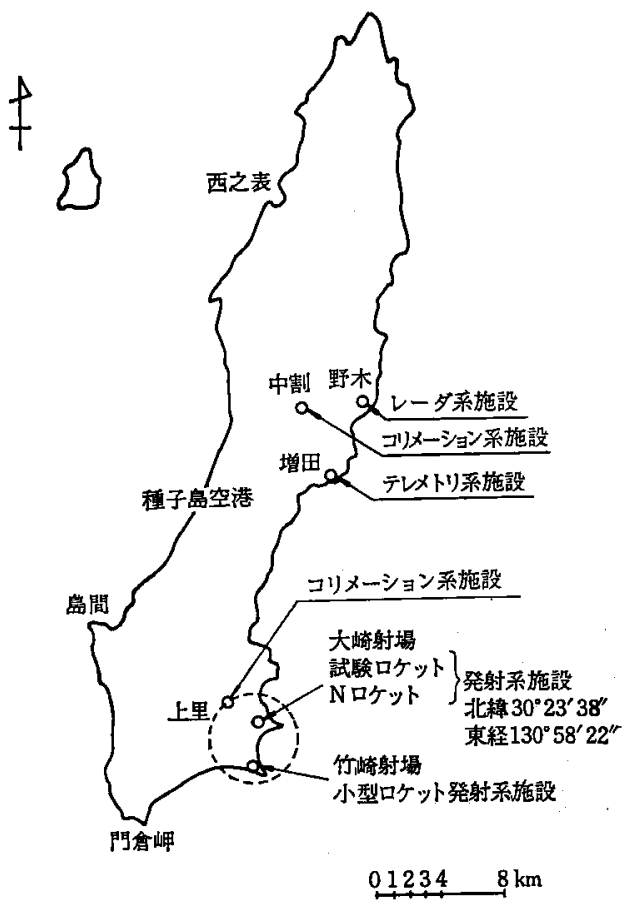

第 12 図種子島におりる施設配置 
第 5 表 筑波宇宙センターの概要（主要機能; ·設備）

\begin{tabular}{|c|c|c|}
\hline 区 分 & 主. 要...機 & 主 要 設 備 \\
\hline 追 跡管 制 系 & $\begin{array}{l}\text { 各追跡局および追跡管制データのコントロール, } \\
\text { 軌道計算および予報など }\end{array}$ & $\begin{array}{l}\text { データ伝送装置，通信連絡装置大型スクリーン． } \\
\text { ディスプレイなよ゙. }\end{array}$ \\
\hline 技術計算系 & $\begin{array}{l}\text { 追跡管制に関する各種シミュレーション,ソフト } \\
\text { ウェアの開発を含む開発技術計算およびこれらの } \\
\text { 業務に直接関係するデータ処理など }\end{array}$ & 䉓子計算機，通信回線など \\
\hline 人工衛星 試験系 & $\begin{array}{l}\text { 人工衛星の機能試験, 人工衛星の環境試驗，試験 } \\
\text { データの觶析処理など }\end{array}$ & 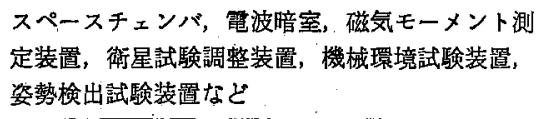 \\
\hline ロケット試験系 & $\begin{array}{l}\text { ロケットおよび搭载機器の機能試醶, 環境試験, } \\
\text { 組立および分離に必要な試験, 䘘星とロケットの } \\
\text { インターフェースに関する試験, コンピュータ, } \\
\text { シミュレーション試験, 試験データの解析, 処理 } \\
\text { なよ゙ }\end{array}$ & 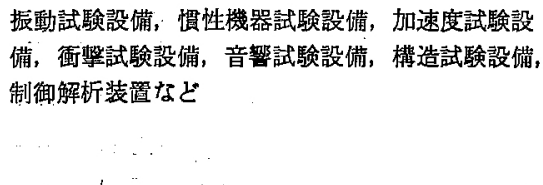 \\
\hline 支援 & 各系への給電, 給排水など & 電力設備, “工作設傹, 給排水設備など \\
\hline 管 理 & 管理事務など & 管理事務所など \\
\hline
\end{tabular}

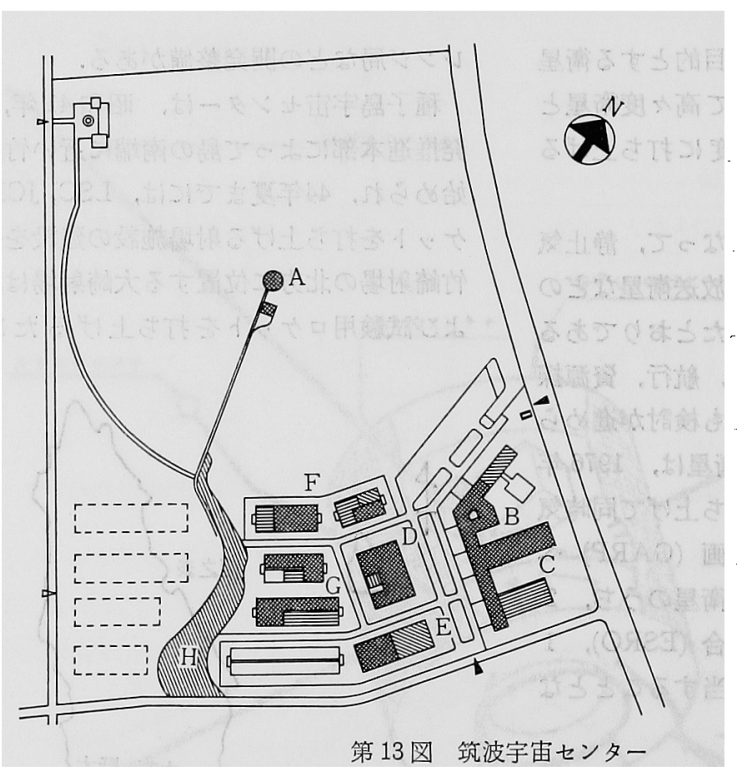
$\mathrm{A}$ : 磁気 試験 場
B：計算センター-
C：追跡管制センター
$\mathrm{D} ：$ スペース・チェンパ
$\mathrm{E}$ : 動力棟・給 水塔
$F$ : 棈, 造 試 験 館
$\mathrm{G}$ ：誘導制御試験館
H：調、整池

O $\quad 50 \quad 100150200 \quad 250 \mathrm{~m}$

在, 両口ヶット捛よび衛星の点検, 組み立, 整備, 発 射に必要な各種施設設備とあわせて，中之山および増 田地区のテレメータ設備, 野木地区のレーダおよび保 安用コマンド設備等の開発整備を急いでいるが，一 部，既に運用を始めているものもある．また，射場の 運営に必要な電力，水等の供給施設や道路等の整備も 進められており，N口ケットの発射に必要なものは， 昭和 49 年度中には一応の完成を見ることとなってい る. 種子島宇宙センターは，衛星やロヶットに対する 将来計画が固まるにつ狆て，順次必要な整借がなさ れ，今後とむ；実用人工衛星に対する発射場として重 要な役割を果たすととになるであるう...(第 4 表，第
12·园)

筑波宇宙センターは，茨城県の筑波研究学園都市の 中の用地に，昭和 46 年から建設が始められた。ここ には，わが国で打ち上げられる衛星の追跡を一元的に 行なう.計算センターのほか，人工衛星やロケットの開 発のために必要な試験装置として，大型スペース。チ ヤンバー，大型残留磁気モーメント測定装置，加速度 衝轷, 音響, 姿勢制御模擬試験装置などの整備が進ん でおり，一部は既に笨用段階に入っている. 将来，筑 波宇宙センターには，さらに各種の試験装置が充奏さ れるとともに，それらを利用した総合的技術解析や技 術情報の収集整備，要員の研修訓練等がさかんに行な 


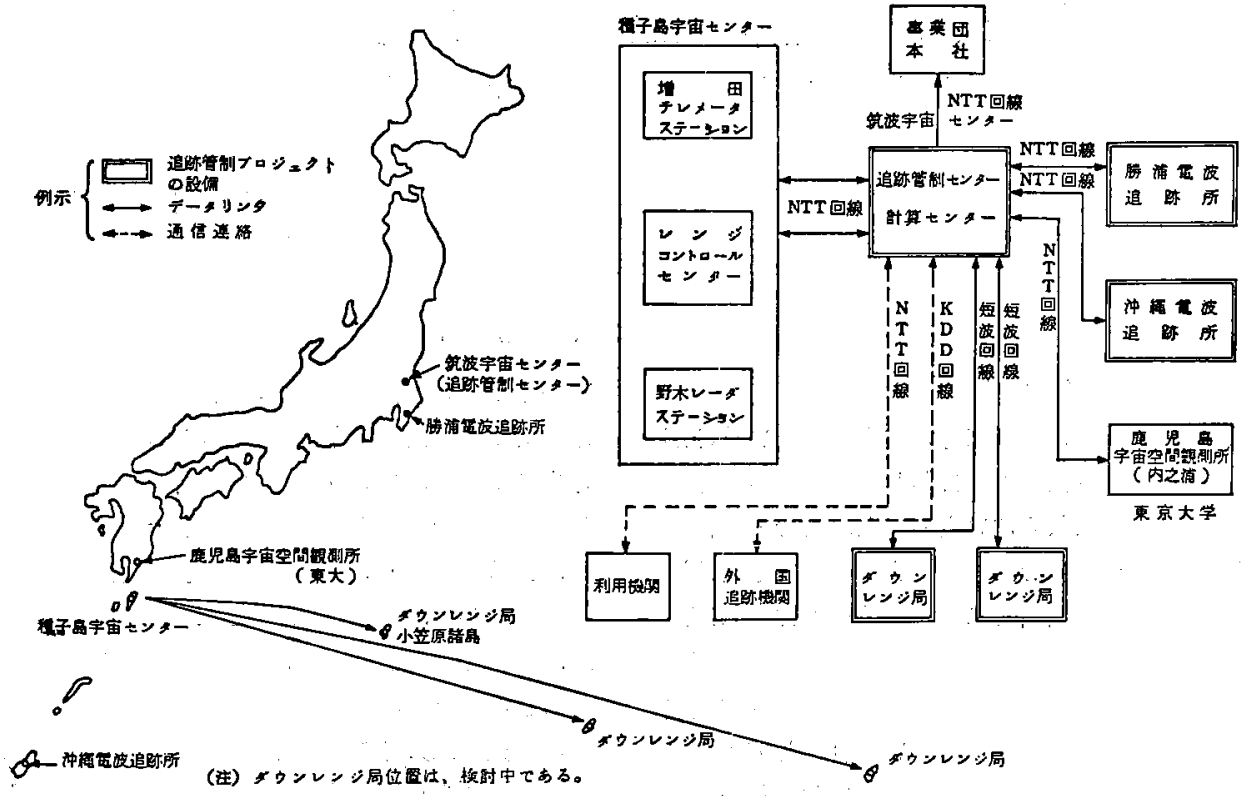

第 14 図，追跡管制の概要（系統）

われることとなるであるう. (第 5 表, 第 13 図)

また，衛星の追跡に関しては，勝浦，沖縄および鹿 览島の観測所と筑波の計算センターでネットワークを 組み，現在は“角度併用ドップラ周波数測定方式”を 採用しているが，将来，実用衛星に対しては，より精 度の高い“距離および距離変化率測定方式（レシジ・ アンド・レンジ・レート)”を用いる予定で準備が進 められている.

一方，小笠原諸島などの海外地域にダウン・レンジ 局を設置しで，口ケットや衛星の飛しょう追跡と安全 保持をはかるため,テレメータ・データの取得とそれ らへのコマンド発信を行なう計画む進められている (第 14 図).

\section{6. むす ひ}

以上， $\mathrm{N}$ 計画について，人工衛星，ロケットおよ び地上施設の面から，開発構想と進抄の現状および将 来の展望などについて概要を記述した，計画を達成す るためには，これらのほか，打ち上げや追跡などの業
務遂行や，全体的な計画と開発の管理を効率よく実施 することが必要である．N計画においては，先進国か らの技術援助を受けたり技術導入をすることが，当面 の開発を進めるための重要な因子となっているが，乙 れは既にたび重ねて述べたように，宇宙開発の塞利用 面に括いて立ち遅れたわが国が，出来る限り早期に， 確寒に，経済的に，先進国の一員として仲間入りする ための実力を婳養をするためである。

宇宙開発は，本来，世界的規模に扔いて行なわれる あのであるが，静止気象衛星の例にも見られるよう に, 将来はますますその様相を強め, 国際協力が重視 されるとと亡なるであろう。ささらに，米国におけるポ スト・アポロ計画の主軸をなすスペース・シャトルが 実用段階に入るのは 1980 年代の初期と見られるが, そうなると, 現在における人工衛星の打ち上げ方や信 頼性の考え方に対して，加な大きな影㖕を及活すこ とになるであろうと思われる.わが国の今後の行方を 定めるにあたっては，これらの情势をあ考虑して検討 することが必要であるう。 